Areas, the meetings were attended by conservationists from many countries in both hemispheres.

Over 40 papers are listed under three headings. Part 1, entitled 'The natural realm in the Arctic', provides background papers on climatic variation and change, marine processes, arctic landforms, floral, faunal and limnological processes, and terrestrial and marine oases. Part 2, 'Land use and conservation in the Arctic', is divided into three sessions and covers a wide range of topics from an overview of northern circumpolar protected areas to fluctuations in caribou numbers, Antarctic protected areas, case studies in tourism and conservation, shipping and marine environmental protection, and applications of the Ramsar Convention to Arctic wetlands. Part 3, 'National parks and protected areas in the Arctic: national overviews' highlights different national perceptions and approaches to parks and reserves in Alaska, Canada, Greenland, Norway and the Soviet Arctic. Each part includes overviews, summaries and discussion papers, and the conclusions accepted by a plenary session on the final day of the symposium are listed.

This must have been a shattering meeting to organize and an overwhelming one to attend; it is difficult enough to digest this account of it, though well worth the effort; most of the contributions are lucid, all are well edited, and they add up to a significant statement by intelligent, concerned people on international cooperation in Arctic planning. One most encouraging conclusion is a mandate for IUCN to study the applicability of Antarctic treaties, conventions and agreements for research, information exchange and resource and environmental management in terms of their applicability to the Arctic area'. If this is a long-winded way of saying that the Antarctic Treaty may have something to offer the north, we can all drink to it. Ecologists have a sound record of international cooperation in the Arctic; perhaps their initiatives will pave the way for the only international agreement that will ultimately make sense for the north, a full Arctic Treaty. (Bernard Stonehouse, Scott Polar Research Institute, University of Cambridge, Cambridge CB2 1ER.)

\title{
ONE MAN'S ANTARCTICA
}

THE ICE: A JOURNEY TO ANTARCTICA. Pyne, S. J. Iowa City, University of Iowa Press. 428 p, illustrated, hard cover. ISBN 0-87745-152-4. \$US37.50.

Stephen Pyne, a historian, has taken trouble to explore scientific aspects of Antarctica in order to write his book. The Ice provides an unusual and interesting perspective that ranges through oceanography and glaciology, geology and geopolitics, literature and history. The prologue to The Ice is the history of an iceberg from source to ultimate destruction; Pyne weaves fact and descriptive passages in an enjoyable and interesting manner. However, in avoiding dry scientific presentation he risks confusing the reader-a simple diagram of Southern Ocean circulation would have been welcome, for exampleand some statements on scientific matters-for example that hydrostatic pressures are higher under ice shelves than under open oceans-do not bear close scrutiny. The author is more comfortable in the general sections. His philosophical chapter on scientific exploration and the opening up of Antarctica is the one which, for me, shows the book's strength. The author develops convincing arguments to account for the stages of Antarctic exploration, and reviews the influence of expedition narratives on contemporary literature and artistic output. Coleridge's 'Rime of the ancient mariner' relied in accounts of Cook's voyages but, Pyne argues, the explorers did not provide imaginative literature; it took others to effect the transformation. Antarctic art has mostly been representational and 
few visitors have developed a style there; Wilson's paintings and the photographs of Ponting, Hurley, Schulthess and Eliot Porter are featured. This unusual combination of scientific, historical and literary aspects of Antarctica is successful and well worth reading, providing a pleasant change from more familiar approaches to the region. (David Rootes, Scott Polar Research Institute, University of Cambridge, Cambridge CB2 1ER.)

\section{BACKGROUND TO DISCOVERY}

ANTARCTIC OBSESSION-THE BRITISH NATIONAL ANTARCTIC EXPEDITION 1901-1904. Markham, Sir Clements. (C. Holland, editor). 1986. Aldburgh, Bluntisham Books and Erskine Press. 179p, illustrated, hard cover. ISBN 094828509 5. $£ 14.95$.

Sir Clements Markham was the principal proponent of British Antarctic exploration at the end of the last century. He recorded the progress of his plans in a detailed document, a Personal Narrative, which was given to the Scott Polar Research Institute by Sir Peter Scott in 1983 . The editor has written a concise and informative introduction which greatly assists the elucidation of this very enigmatic record. Much of it reports the intrigue and other circumstances of Markham's manipulation of several different (and frequently disagreeing) organizations to enable the Discovery (1901-04) expedition to take place. The account is outspoken and, eighty years ago, was quite confidential-including personal opinions of many of those involved. Now it provides a most interesting and distinct idea of events at the times, and perhaps an idea of situations prevailing more generally. The editor has included a concise biography of Markham, brief biographies of the more important of the others involved, and some general notes. Unfortunately the quality of the printing is rather poor. (R. K. Headland, Scott Polar Research Institute, University of Cambridge, Cambridge CB2 1ER.)

\section{VITAMIN C IN EXPLORATION}

THE HISTORY OF SCURVY AND VITAMIN C. Carpenter; K. J. 1986. Cambridge, Cambridge University Press. 288p, illustrated, hard cover. ISBN 0521320291 . 227.50

This is a very comprehensive and fascinating account of one of the diseases which has had the most significant effects on the history of travel and exploration. It is the second of the author's studies in deficiency diseases; his account of pellagra was published in 1981. The information is investigated on a historical basis, beginning in the middle ages and finishing with a discussion of recent 'mega-vitamin' contentions. A final chapter Retrospect covers a variety of special matters and enigma. The author has been careful in providing information for the reader, and in many cases cites primary sources where there is disagreement in interpretation. The Treatise of the Scurvy..., written by James Lind and published in 1753 is the most important historical development in the knowledge of the disease. The development of Lind's theories and particularly his experiments (one of which was probably the first controlled trial in clinical nutrition) is well described. Unfortunately Lind's ideas did not become generally applied (although there were several notable exceptions), and many lives were lost as other theories were acted upon. The development and consequences of these circumstances are concisely given. Captain James Cook was probably the second most important person in the history of scurvy; the author gives an account of his methods, including making sauerkraut a delicacy for officers in order to encourage the seamen to accept it. One chapter 